Doctor of Historical Sciences (Dr. Hab. in History), Professor, Head of the Department of World History, H.Skovoroda Kharkiv National Pedagogical University, (Kharkiv, Ukraine), lerche555@ukr.net ORCID: https://orcid.org/0000-0002-1249-2482?lang=en

\title{
YOUNG PEOPLE MOBILIZING FOR PARTICIPATION IN COMMUNISTIC TRANSFORMATIONS IN RURAL AREAS DURING THE YEARS OF THE COLLECTIVIZATION AND HOLODOMOR
}

\begin{abstract}
The purpose of this study is to analyze the participation of students and teachers of Ukrainian higher education institutions in the Soviet transformations in the countryside and outline their role in organizing the artificial famine. The research methodology is based on the principles of historicism, scientificality, interdisciplinarity and anthropocentrism. To solve the problem, the method of socio-cultural analysis is used, as well as traditional concrete-scientific methods: historical-genetic, problemchronological, comparative and typological. The scientific novelty. The article analyzes participation of students and professors of Ukrainian higher education institutions in the countryside during the years of collectivization and the Holodomor. The research is based on a wide range of sources, among which a special place belongs to ego-documents: diaries, letters to the authorities, unpublished memoirs. Strategies for student behavior regarding the implementation of the decisions on participation in collectivization, collection of grain for the state grain stockpile and harvesting campaigns and the forms of their protests are highlighted. It is identified that a significant number of students were psychologically not prepared to carry out this work, therefore, they refused to go to the villages, fled from there, wrote letters to the authorities criticizing the party's policy in the countryside. An extreme form of protests was suicide. The types of punishment that were used for students who refused to work in the countryside are identified. The attitude of students and teachers towards peasants, their relations are revealed, as well as their reflection on the situation in Ukrainian villages and on the everyday life of rural party activists and their families in the spring and summer of 1933. Conclusions. The analysis of the students' participation in collectivization, sowing, collection of grain and crop harvesting campaigns shows their significant role in carrying out these activities. The high school was transformed into an inexhaustible source of a constant supply of human resources for local Soviet structures, for replenishing the brigades of collectivists and liquidators of numerous gaps of Soviet construction.
\end{abstract}

Keywords: students, teachers, Holodomor, mobilization, peasants, collection of grain.

Since late 1980s, the Holodomor has been subject of debate and public scrutiny. Scientists have made a lot of efforts to prove a deliberate creation of the Ukrainian village of 1932-1933, during Stalin's "revolution from above", during which physical survival of a person became impossible. Literature on the Holodomor issues of 1932-1933 in Ukraine currently has more than 20 thousand items ${ }^{1}$. However, to this day, scientists are arguing about the total number of victims and the discussion on the national identity of the Holodomor victims

1 Кульчицький С. Голодомор 1932-1933 років у світлі останніх досліджень // Світогляд. 2013. - №5 (43). - C.70. 
remains relevant. In addition, new aspects emerged in the study of the Holodomor; in particular, the performers of the Holodomor, namely those who undertook the execution of criminal acts on the ground. One of such performers, Lev Kopelev, later known as a famous writer and literary critic, in describing his own experience as such a performer in the Myrhorod district (in Ukrainian - raion) of the Poltava region (in Ukrainian - oblast; formerly known as the Kharkiv region territory) noted that "it is impossible to atone this sin and avert by praying" 2

The average executives of the Holodomor, in the vast majority, remain nameless today and have not become the subject of a separate study. This was emphasized, for example, by Olha Andriewsky3. Indeed, this is caused in part by the relatively recent interest in researching the topic, limiting the amount of attention that has been devoted to it, and the dispersed locations of the relevant documents and sources. Nevertheless, while an aggregated list of the performers does not currently exist, it has become possible to start elaborating one.

The purpose of this study is to analyze the participation of students and teachers of Ukrainian higher education institutions in the Soviet transformations in the countryside and outline their role in organizing the artificial famine. The research is conducted in the methodological framework of the history of everyday life and is based on a wide range of sources. Among them, a special place belongs to ego-documents, such as diaries, letters to the authorities, unpublished memoirs, as well as party documents and visual sources.

Sheila Fitzpatrick noted that the younger generation played a leading role in implementing the collectivization ${ }^{4}$. It should be noted that the country's authorities regularly used the youth to implement their plans. All Soviet transformations were carried out with the direct participation of students as the most organized and mobile social group. This is evidenced by numerous decrees, orders and instructions on mobilization of so-called "breakthroughs" including "arrear" of the Ukrainian village.

From the end of the 1920s to the early 1930s, students sent by the party and Komsomol authorities had to take a direct part in the collectivization, sowing, collection of grain and crop harvesting campaigns. In 1929, it was recommended to officially mobilize only the students of the second and third year of the agricultural higher educational establishments ${ }^{5}$. The rest of the institutions had to show their own initiative "regarding the agro-cultural assistance in carrying out preparatory work for sowing, help in organization of collective associations in the countryside"6.

It was mainly the students from the peasants' environment who were sent to support the collectivization. A student of Kharkiv Institute of Public Education

${ }^{2}$ Копелев Л. И сотворил себе кумира. - Х., 2010.

${ }^{3}$ Andriewsky O. Towards a Decentred History: The Study of the Holodomor and Ukrainian Historiography // Contextualizing the Holodomor: The Impact of the Thirty Years of Ukrainian Famine Studies / Ed. by A.Makuch, F.E.Sysyn. - Edmonton; Toronto, 2015. - P.18-52.

${ }^{4}$ Fitzpatrick Sh. Education and Social Mobility in the Soviet Union, 1921-1934. - Cambridge, 1979.

${ }^{5}$ Центральний державний архів вищих органів влади та управління України (далі ЦДАВО України). - Ф.166. - Оп.9. - Спр.1736. - Арк.266.

6 Там само. 
O.M.Matvienko remembered that in the early spring of 1929, having stopped their studies, they left for the villages of the Kharkiv region. "It was offensive to realize that the students who were not from peasant backgrounds stayed in the city and continued their studies"7.

According to the decisions of the December plenum of the Central Committee of the $\mathrm{CP}(\mathrm{b}) \mathrm{U}$ (1930), the teaching staff of the pedagogical schools, "without wasting a single day", "with even a greater zeal" had to set up to work and make all the students be more active. In addition, every twenty days, it was necessary to submit to the People's Commissariat of Education (PCE) the information "about the participation of the pedagogical school in preparation for spring sowing and the following of seeding", and the first notification had to be submitted by January $20,1931^{8}$.

Since then, the registration begins of mass and permanent mobilizations of students to the village, which increased in number with every following. The newspapers using the slogans: "In a march for a socialist village!", "Student in the struggle for the second/third Bolshevik spring", reported the "initiative" of a particular group of students or individuals that everyone should take up. In the University paper of Kharkiv Institute of National Economy of February 22,1930 , it was written:

"Particularly important is the initiative of the students of the
4th year of the Trade Faculty: they decided to take a break in
the study and go for a month to the village to participate in the
preparation for sowing. The authorities of the Institute met this
initiative half-way. All the students of this year, both party mem-
bers and non-party members, decided to go unanimously. This
initiative should be supported by all the 4-year students"9.

The directors of higher education institutions reported to the People's Commissariat of Education that they had begun the preparation for the next Spring's agricultural campaign even before the relevant directives had been issued. Thus, Odesa Physical-Chemical-Mathematical Institute reported: "Since during the winter holidays in January 1931 a number of students had to go to the villages, they had been trained as for their tasks in the village. For this purpose, two seminars were held, which were visited by almost all the students who went to the villages (68-70 people)"10.

It is hard to estimate the number of campaigns that were conducted. Indeed, there were many campaigns aside from the renowned and widely covered allUnion campaign, also known as the Campaign of the 25-thousanders, during

7 Матвиенко А.М. Харьков. ХИНО-ХПИПО // Харківський університет (1917-1941рр.) у спогадах його викладачів та вихованців. - Х., 2016. - С.111-121.

8 Держархів Одеської обл. - Ф.Р-1641. - Оп.1. - Спр.12. - Арк.1.

9 Гаркавенко. Бажаємо успіху. 4-й курс торгфаку вирушив перший // Студент Жовтня: Орган студентів, професорів, викладачів та службовців інститутів: інженерно-економічного, пляново-економічного, обміну й розподілу та радянського будівництва і права (Харків). 1930. - 22 лютого.

10 Держархів Одеської обл. - Ф.Р-1641. - Оп.1. - Спр.12. - Арк.2. 
which students were sent to villages for the success of "collective-farm construction" due to the decision of the November plenum of the Central Committee of the All-Union Communist Party of the Bolsheviks ${ }^{11}$. Higher educational institutions and other organizations conducted constant correspondence with the party committees of various levels on mobilization to the rural areas of " 50 ", " 100 ", "150", “300", “800", “1100", "2000" etc. ${ }^{12}$.

The elaboration of reports on the state of work in the villages and the number of students sent there was mandatory. These numbers are impressive. The Stalin Mining Institute reported that "at the time" of delay "with collectivization 150 students worked in the villages, there were 290 students employed in the harvesting campaign". In parallel, other students were employed in the industrial sector for the "elimination of the breakthrough of the industrial financial plan more than 1000 people worked at a plant, and on the Day of Strike Workers, 1200 students were employed. 55 comrades work at a plant permanently" ${ }^{13}$. We have similar information on other universities as well.

Of course, much attention was paid to the participation of the party and the Komsomol members in these campaigns as this was their direct duty. Thus, the Kharkiv Machine Building Institute reported that 645 of the 1427 students were members and candidates of the party at the beginning of 1932/33 academic year. Only in February - March of 1933, 152 people were sent to various campaigns, and 81 students were sent to permanent employment in political departments and machine-tractor stations (MTS). Later, 79 students sent for the sowing campaign joined them ${ }^{14}$.

The documents clearly show that all students, regardless of their party membership, participated in the mobilization processes. This work was particularly intensified in the 1932/33 academic year.

At the All-Ukrainian meeting of Heads of the regional departments of public education on February 18, 1933, the public education bodies were criticized as, in the period of struggle for bread, they had not "organized a mass political work among collective and individual farmers, among the bodies of active collective farmers and having not appropriate forms and methods of work, did not provide a full mobilization for the implementation of the annual plan for collection of grain for the State's grain stockpile and the destruction of kurkuls' sabotage" 15 . It was decided to devote more "attention and energy, class vigilance" to the next spring sowing campaign "to fulfill the tasks of the $4^{\text {th }}$ Bolshevik Spring, in the

11 Lynne V. The Best Sons of the Fatherland: Workers in the Vanguard of Soviet Collectivization. New York; Oxford, 1987; Конквест P. Жнива скорботи: Радянська колективізація та голодомор. К., 1993; Фицпатрик Ш. Сталинские крестьяне: Социальная история советского общества: деревня. - Москва, 2001.

12 Держархів Одеської обл. - Ф.11. - Оп.1. - Спр.108; Центральний державний архів громадських об'єднань України (далі - ЦДАГО України). - Ф.1. - Оп.20. - Спр.6222. - Арк.20, 42; Держархів Харківської обл. - Ф.2. - Оп.1. - Спр.62. - Арк.8, 26; Спр.61. - Арк.5, 34; Спр.69. Арк.72; Спр.70. - Арк.103; Спр.76. - Арк.103, 145-146 та ін.

13 ЦДАГО України. - Ф.1. - Оп.20. - Спр.5558. - Арк.110.

14 Там само. - Арк.102-103.

15 ЦДАВО України. - Ф.166. - Оп.11. - Спр.39. - Арк.9. 
struggle for strengthening the collective farms, for raising yields" ${ }^{16}$. Therefore, at the peak of the Holodomor, in the winter and spring of 1933, for the entire time of the fieldwork, the brigades of students were sent to work in different villages to eliminate the "seed breakthrough" to harvest seed and do sowing. It was considered necessary to mobilize the students of the agricultural universities "as controllers and political leaders of the collective farmers brigades", which was discussed, for example, in the resolution of the Kharkiv Regional Committee "on mobilization of '2000' for the period of spring sowing” of March 28, $1933^{17}$.

In the summer of 1933, senior students and postgraduate students (party or Komsomol members) were selected for the agrotechnical propaganda. This youth had to teach the peasants the correct forms of organization for harvesting, threshing and preparation for autumn sowing ${ }^{18}$. The decisions to mobilize students to the villages for a variety of work were taken on a permanent basis. For example, the Secretariat of the Kharkiv Regional Committee of the $\mathrm{CP}(\mathrm{b}) \mathrm{U}$ on June 24, 1933, made two decisions on mobilization: for the period of the twomonth harvesting campaign, 76 students of Kharkiv and Poltava higher educational establishments were placed at the disposal of the regional department of the Chief Political Administration, while others had to be selected and sent for 10 days to the rural areas to help MTS ${ }^{19}$.

It is not currently possible to know how many students were sent to work in the villages. Statistics was conducted for individual campaigns (both in the regional party committees, and in the institutes), but it is difficult to find it all. The consolidated data for all the years of mobilization, probably, has not survived. However, the available documents provide interesting observations. Amongst these, the graphs provide the following information on individual campaigns: district, responsible person, number of party members, Komsomol members and, separately, students. In some areas there were no responsible people, perhaps there were simply not enough of them. For example, in 13 districts out of 50 districts of Odesa region in the spring of 1932, only students were involved in sowing campaigns! Of course, there were also local activists. Out of 818 people sent to the villages at that time, 373 were students. The number of the students was not constant, but the tendency was on the rise. As a result, the same list was supplemented and the number of the students increased to 96 . Thus, we can conclude that out of the total number of the people mobilized to the village, the majority were students ${ }^{20}$.

In Poltava Institute of Social Education, in 1933, a headquarter was working, which regularly sent brigades out of students and professors to the assisted and other villages designated by the party committees. Separate groups, faculties, or even the whole staff of the Institute could be sent ${ }^{21}$. The brigades were continuously sent from the Nizhyn Institute of Social Education: one brigade

\footnotetext{
16 Там само. - Арк.10.

17 Держархів Харківської обл. - Ф.Р-2. - Оп.1. - Спр.62. - Арк.26.

18 Там само. - Спр.73. - Арк.62.

19 Там само. - Спр.74. - Арк.90, 113.

${ }^{20}$ Держархів Одеської обл. - Ф.Р-11. - Оп.1. - Спр.112. - Арк.80-81.

${ }^{21}$ ЦДАВО України. - Ф.166. - Оп.11. - Спр.148. - Арк.116.
} 
was replaced by another ${ }^{22}$. And as of July 1,1933 , all the students and the teaching staff of the pedagogical institutes self-mobilized for the harvesting campaign for a month ${ }^{23}$.

Youth was mobilized for different periods. It could be a couple of weeks or several months. Sometimes, at the request of regional party structures and with the permission of the higher educational establishments, the students were left for a new term, and even for a permanent work. Thus, on March 4, 1932, the Novo-Ukrainian Regional party committee reported that out of the students of the brigades sent by Kharkiv and Odesa, only eight people remained in the region, who were asked to be left for the sowing campaign. The order was given without the students' approval! ${ }^{24}$ Thus, a student of Odesa Industrial Institute, V.Novikov, in his letter to the Dean, asked to help and bring back his brother N.P.Bulat, a student of the $4^{\text {th }}$ year, as he was sent by the local party committee on July 14, 1933, from the village to the crop harvesting. But since the annual grain delivery plan was not implemented, the local party committee allowed for a part of the students to be left to work permanently: "I hope, - V.Novikov wrote, - that the authorities of the institute will help him to get back and finish the studies" ${ }^{25}$.

It is important to note that these students were not offered extensions or additional time to pass their examinations. After their mobilization to the village, even for a long period of time, they returned to the students of their year of studies and had to master all the disciplines individually. Exceptions to the rules occurred, but they were infrequent. For example, a student of Kyiv Industrial Institute Drenov was indignant at the fact that two girls of the senior year of study, Jews by nationality, were enlisted in his group after the mobilization. He said that "this is their privilege as Jews" ${ }^{26}$. The emphasis was on the privileges that were said to exist for Jews. In reality, such exceptions to the rules did not depend on the nationality of the students but simply on anti-Semitic sentiments that were common at that time.

In addition, mobilized young people were often transferred to other places after the expiration of their term. Thus, the student of the Kharkiv Institute of Public Education Ivan Plakhtin wrote that he "was drowning in orders [...] and then almost became an authorized representative of the Central Committee and the regional committee of the $\mathrm{CP}(\mathrm{b}) \mathrm{U}$ on sowing, harvesting, collection of grain, breakouts in the Donbas, etc." ${ }^{27}$. We also read in the memoirs of P.A.Havriuk, that he studied at the Literary Department of Kyiv State University, but due to the order of Kyiv regional party committee, had various employments, in particular in the Shpolianskyi district, where he worked in the MTS political department. Later, he wrote that he was proud to have participated in the strengthening of

22 Там само. - Арк. 70.

23 Там само. - Арк.117; Держархів Хмельницької обл. - Ф.302. - Оп.1. - Спр.1841. - Арк.41, $75,105$.

24 Держархів Одеської обл. - Ф.Р-11. - Оп.1. - Спр.112. - Арк.31.

25 Там само. - Ф.Р-126. - Оп.1. - Спр.2. - Арк.8.

26 ЦДАГО України. - Ф.7. - Оп.1. - Спр.1079. - Арк.53.

27 Плахтін I. Літа-дороги: Спогади. - Сімферополь, 1982. - С.117. 
the collective farming system, and that he passed his graduated exams at the university, together with his fellow-students while working in the village ${ }^{28}$.

The Heads of higher education institutions, who initially enthusiastically ensured the party bodies and PCEs of the readiness of higher schools to participate in mobilization campaigns, later increasingly appealed to the party bodies and asked to return students, especially freshmen, since "staying out of school will not allow them to catch up with their comrades, who are studying" ${ }^{29}$. This is evidenced by their letters to the authorities that have been preserved in the archives. Thus, the Director of Kherson Agricultural Institute Symonko, in response to the order for a new mobilization of the third-year students for the crop accounting for a month on June 16, 1933, asked to stop taking the young people out of classes because "implementation of the curriculum, the academic session, diploma works is disrupted" 30 .

Such requests, as a rule, remained unanswered. However, we have some data testifying that the senior management still agreed to return students to their educational institutions. Thus, on July 4, 1933, the Central Committee of the $\mathrm{CP}(\mathrm{b}) \mathrm{U}$ sent to all the regional committees a telegram signed by S.Kosior, which ordered: "Ensure the return of the students who are involved in the harvesting campaign, no later than August 20. Provide students with footwear, clothes and linen" ${ }^{31}$. Similar orders were made in the following year, which testifies to the continuation of the practice of using students' labor in the agricultural work during the academic year. For example, on April 1, 1934, all secretaries of the regional committees sent a telegram signed by the secretary of the Central Committee of the $\mathrm{CP}(\mathrm{b}) \mathrm{U}$ P.Postyshev, which stated that "the Central Committee categorically binds, within two days, to return to studies all the students of Kharkiv Institute of Mechanization, mobilized by the Central Committee as teachers of the courses, foremen, mechanics, tractor drivers, combine operators" ${ }^{32}$.

Taking young people out of their classes, the authorities made them fulfill the work that the peasants refused to do.

\begin{abstract}
"Not stuffy classrooms, lectures and theoretical formulas but an immediate facing of the class struggle - the struggle for bread, for new collective farms, for the Bolshevik sowing, organization of labor, shock working, social competition should become the laboratory of daily work of the student brigades in the country" 33 .
\end{abstract}

28 Гаврюк П.А. Робітфак індустріального гіганта: Спогади // Український історичний журнал. - 1971. - №1. - С.106.

${ }_{29}$ Держархів Одеської обл. - Ф.Р-11. - Оп.1. - Спр.108. - Арк.114-115.

${ }^{30}$ ЦДАГО України. - Ф.1. - Оп.20. - Спр.6451. - Арк.28.

31 Там само. - Спр.6222. - Арк.57.

32 Там само. - Спр.6451. - Арк.16.

${ }_{33}$ Мирошник П. В боротьбі за другу більшовицьку // За механізацію та електрифікацію сільського господарства: Двотижнева газета студентів, медперсоналу та співробітників Харківського інституту механізації та електрифікації сільського господарства. 1931. - 14 травня. 
The newspapers reported that "the best representatives of the proletarian students" went to villages "with songs, full of vivacity and Bolshevik enthusiasm". It should be noted that the geography of the trips was wide and not limited by the close villages or the oblast. For example, " 65 best representatives of the proletarian students of Kharkiv Institute of Mechanization and Electrification of Agriculture - 5 shock brigades of enthusiasts of the II Collective Farming Spring" were sent to the Melitopol district ${ }^{34}$. It was possible to meet the representatives of other universities of Kharkiv in the Odesa region, Dnipropetrovsk region; the students from Odesa were sent to the Vinnytsia region, the Moldavian Autonomous Socialist Soviet Republic, and so on.

Getting to distant areas was difficult. A student of Kharkiv Institute of Vocational Education Ivan Plakhtin, who in the spring of 1932 was sent as an authorized representative to the sowing campaign in the village Prachi of the Hlobyne district, recalled that he was walking to this distant village for about twenty kilometers in mud and even lost his soles ${ }^{35}$. The students of Kharkiv Institute of Mechanization and Electrification of Agriculture walked $80 \mathrm{~km}$ to Kakhovka machine-tractor station because they had no money for transport ${ }^{36}$.

Students were sent out to organize collective farms, to repair the equipment, to conduct cultural and educational activities among the peasantry (conversations, reading newspapers), to produce wall papers, breaking newspapers, and the like ${ }^{37}$. Even the student, who came from villages, did not have enough experience of working in agriculture, but young people were forced to take work to avoid punishment. So, the secretary of the Hlobyne District Party Committee said directly to Ivan Plakhtin: "I will either organize and conduct the spring sowing well or will be booted from the party" ${ }^{38}$.

Most of the students took the physical work with enthusiasm. It was similar almost in all villages. Documents and even diaries say that the people worked joyfully, with songs and jokes. Thus, in Hurynivka the students repaired 40 drags, examined 30 seeding machines, repaired a locomobile, collectivized all the horses of the village and shoed them; they completed the plan for collecting of the seed material by $100 \%{ }^{39}$. In the Raihorodok village, the students purified and collected the storage seed fund, exceeding the district plan, repaired the collective farm remnant and acquainted the peasants with the plan of sowing. A lot of these facts can be provided.

The peasants who refused to work in collective farms were perceived by such party messengers as enemies. M.K.Sinkov, for example, noted in his diary an impression of his meeting with rural youth:

34 Там само.

35 Плахтін I. Літа-дороги. - С.117.

36 До третьої більшовицької весни // За механізацію та електрифікацію сільського господарства. - 1932. - 15 лютого.

37 Гладштейн. Студентство ХІРБП в боротьбі за збір урожаю // Студент Жовтня. 1931. - 5 липня.

38 Плахтін I. Літа-дороги. - С.116.

39 Гуринівка має бути зразковим колгоспом: Шефбригади - на допомогу селу // Студент Жовтня. - 1930. - 22 лютого. 
"Some peasant boys appeared in the field, who lazily talked shaking seeds and looking at us. We asked them why they are not working and why in general, no peasants are present in the field, except the bosses. One of them replied: 'You will work for us!' and the rest laughed. It was a laugh of an irreconcilable enemy, which caused a great indignation and hatred in me" 40 .

Many students, who were the participants of the mentioned historical events, believed in the necessity of collectivization by violent methods, and sincerely hated the "kurkuls" and other "class enemies" as they were convinced in their institutes that "kurkuls and their followers" operate in the villages". At the time of the arrival of the brigade from Kharkiv Planning Institute of Consumer Cooperatives in Raihorodok of the Sloviansk district (February 1, 1931), 106 households $(35,3 \%)$ out of 761 were organized into the collective farm of the village. According to the local newspaper, a month later, on March 1, 58\% of the households joined the collective farm ${ }^{42}$. And the secretaries of the party and Komsomol committees of Raihorodok were accused of opportunist views for not noticing the great "kurkul slogan": "Collectivist, do you think that further development of the collective farm and your prosperity is possible?" 43 .

The results of the work were widely covered in the periodicals, and the importance of this work was stressed constantly: "All this specifically indicates that the directive of the party on mobilizing students to the country has been fully justified", "The more such people are sent the better the situation will be"). The articles pushed the youth for further participation in "shock combat work"

It should be noted that the result of the work depended on many factors, including the ability to convincingly explain the task to the peasants, and establishment of good relations with the local population. These relationships evolved differently. The aforementioned Ivan Plakhtin, who assembled a meeting of the collective farmers and talked about the need to sow spring cultures in a good time, was almost killed by women, who attacked him with a cry: "Beat the dumb chatterbox" ${ }^{45}$. He lost consciousness as he was hit by a beater on his head. It saved him. The future writer recalled: "A beautiful high-handed widow, in order to somehow reclaim fault, mobilized the collective farmers, persuaded them to harness private cows into seeding machines and harrows. [...] They finished harvesting on time, and when young crops of spring wheat turned green, satisfying the eye the District Committee sent me back home with a gratitude" ${ }^{46}$.

A student of Kyiv Institute of Public Education, a future professor Yu.Kobyletskyi, had a similar incident in the village of Mudrivka near Chyhyryn. He and other collective farming activists "were locked up in the village council by

40 Держархів Харківської обл. - Ф.Р-6452. - Оп.1. - Спр.5276. - Арк.159 зв.

${ }^{41}$ ШШnорт A. Беззаконня: Нотатки репресованого // Київ. - 1991. - №7. - С.8.

${ }_{42}$ Каневські A. ma H. Студентство у боротьбі за другу більшовицьку весну // Студент Жовтня. - 1931. - 13 квітня.

${ }_{43}$ Там само.

${ }_{44}$ Мирошник П. В боротьбі за другу більшовицьку.

45 Плахтін I. Літа-дороги. - С.117.

46 Там само. 
women, were guarded for several days and given only water to drink through the window but no meals. They yelled at [them] like nothing on earth: passionately, hysterically and partially" 47 . For some people such cases remained like adventures of the youth but for others they ended tragically. For example, during an attempt to organize a collective farm, Anton Pidopryhora from Kyiv Institute of Public Education was killed ${ }^{48}$.

We cannot, unfortunately, answer the question of how often such cases occurred, and moreover, to show them as a percentage. There were the brigades of students who declared themselves shock workers and "ruthlessly fought the kurkuls, introducing the party's general direction”. Such students of Kharkiv Institute of Exchange and Distribution as Yakovlev, Lozhkin and Kozinets worked in Baranovo village in the Kharkiv region from February 3 to April 10, 1931, and called to look to the "best comrades - social activists" 49.

Fighting with "kurkuls and their followers" was reported with special pride, especially during the Holodomor years. Reports of the Institutes give an idea of the scale of this work ${ }^{50}$. It is known that in some villages, students performed the task of seed material collection almost entirely. For example, 40 students of Lubny Institute of Social Education collected 90\% of the necessary seed material during the decade of work in the spring of 1933 in the Lubny district of the Poltava region and "exposed the kurkuls who maintained resistance" 51 . These activists were particularly proud of the fact that in the village of Snityn they exposed "an armed gang headed by the Kotliars (sons of a kurkul)", and in the villages of Dukhova, Kozaidentsi and Khyttsi found "the kurkuls who organized the theft of a haycock from the collective farm field and the theft of horses" 52 . The authorities of Mykolaiv Shipbuilding Mechanical Engineering College reported with pride that their students in the village of Slyvino had "mobilized $96 \%$ of the seed material, organized the guard, repaired the agricultural remnant, organized the brigade of seeders", and in the village of Vodopii, "36 centers of concealed kurkul's bread" were collected ${ }^{53}$. But Kharkiv Physical-ChemicalMathematical Institute was disgraced by the fact that the "preparation for the spring was missed" - only $3,96 \%$ of seeds were collected in the village. One representative of the institute lived permanently in the village and two more came to help him, which caused a considerable concern of the party bodies ${ }^{54}$.

Ego-documents help us to imagine how the Ukrainian village of 1932-1933 looked like, how the young people perceived it and treated their work. Some people were "restrained by an oppressive silence". A.Shport wrote in his memoirs that it was impossible to imagine a Ukrainian village without singing, noise,

47 Кобилецький Ю. Даль махне крилом. - К., 1985. - С.134-135.

48 Там само. - C.138.

49 К. Гарні наслідки роботи // Студент Жовтня. - 1931. - 1 травня.

${ }^{50}$ ЦДАВО України. - Ф.166. - Оп.11. - Спр.148.

51 Добровільна. Лубенці знайшли основну ланку // Студент револющії (Харків). - 1933. №7/8. - C.3.

52 Там само.

53 Рапортуемо наслідками бойової роботи // Там само. - C.4.

${ }_{54}$ Волошина С. Визнати помилки - виправити хиби // Там само. - C.5-6. 
dog barking, cock screaming ${ }^{55}$. The most shocking display of oppressions is illustrated by the peasants who found the strength to go to work:

\begin{abstract}
"It's hard to figure out if it is a young or an old woman, a teenager or a girl. All people had the same look and similar faces. The hunger made everybody equal [...] What could one and a half or two dozen exhausted women do? They moved slowly and were frequently sitting on the rows of beets, abundantly covered with weeds" 56 .
\end{abstract}

According to the memoirs of L.Vysheslavskyi, on the beet plantations the students were impressed by the fact that hungry people drank treacle, which was needed to catch an owl moth, picked up and ate ant eggs. And one of the students gave half of his ration to a girl swollen from starvation ${ }^{57}$.

At the same time, one could notice another lifestyle, namely, the way the local party elite lived. In the diary of Anton Komashka (former student I.Repin, a talented artist, director of the Kharkiv Art Institute), the everyday life of one of families such as the family of the Chairman of the Velyko-Bahachanskyi district financial department Fedir Nechytailo, is described in the smallest details. His family lived in the village of Zatin (now - Poltava region).

"Among typical peasant buildings there was a new house of Nechytailo covered with gray tiles. Inside the house - an amazing piece of the holiday. The ground floor is covered with fresh grass. The aroma of grass, in snow-white embroidered towels, in a red wooden sofa along the entire wall - all these made a sweet coziness, which reminded a folk poetry. But new things were also embedded: a telephone, a radio, portraits of Lenin, Stalin and Shevchenko. As a final chord, there was a bouquet of red dahlias on a table, on a clean tablecloth" ${ }^{58}$.

But most of all the artist was struck by the beauty of the young lady, Maria Ivanivna, the wife of Nechytailo! And though his task was to create a gallery of local collective farmers, he wrote a portrait of this woman too. In the diary he noted: "In my mind, I expressed my surprise in such a way: here it is, the work of the life itself, so perfectly composed. Young, healthy, beautiful Ukrainian woman, tanned, with brown, lively, red lips with a smile, dimples on her cheeks [...] smart, playing eyes" ${ }^{\text {" }}$. What a contrast it was with the portraits of Ukrainian peasants who lost their minds or died of hunger in polluted, cold huts! Or to the portraits of women of the collective farms, who used the rest of their energy to go and work in the field.

The eye of the artist captures and describes the differences in the nutrition of the collective farmers and their leaders. Here are some descriptions:

${ }_{55}$ Шnорт А. Беззаконня: Нотатки репресованого. - С.9.

56 Там само.

${ }^{57}$ Гончар О. Щоденники: У 3 т. - Т.2 (1968-1983). - К., 2008. - С.206.

58 Центральний державний архів-музей літератури і мистецтва України. - Ф.290. - Оп.1. Спр.139. - Арк.10.

59 Там само. - Арк.11. 
"August 5. I traveled on a horse cart to the fields. I made 5 sketches of the best collective farmers, men and women. [...] One of the collective farmers asked us: 'When will you stop feeding us with this dung, hell with them. Have you shown them to our managers?'. And the woman who was driving the horse cart told me that she was swollen, when she worked collecting beets".

Another story: "When I was making sketches of mowers, during the break for breakfast one of them said showing a cookie: A good household owner will never feed a dog with such a thing. But the dog will never eat it, it will just smell it and go away. Well, you know, it is stuck in the throat here (he showed on the chest)" 60 . There was quite a lot food in the house of the already mentioned F.Nechytailo: "[...] we found a full table of snacks, bottles, and all was crowned by fried fishes (breams, crucians, pikes). If in my life I had occasions of a wonderful pastime, that day and evening I believe to be the most outstanding. What a cheerful talk, full of folk says and paradoxes. And how Maria Ivanivna was laughing! [...] In a warm, starry Ukrainian night, we returned in a horse cart to Velyka Bahachka. Potapenko's booming laughter expanded in the meadows, in the dark, among the dewy, fragrant herbs and the river Psiol"61. It was laughing at the time when most of the people had forgotten what a laugh was.

The artist assumed that his diary would be read sooner or later. This is evidenced by many details, in particular, the way he carefully copied the letters of I.Repin with a high appreciation of his work to the new notebook. A.Komashka was a convinced communist as well as many other artists of that time, he often fulfilling the tasks on propaganda. Adding to the gallery of shock workers of the Velyko-Bahachanskyi district the representatives of the local party nomenclature and the members of their families (as many as 33 portraits were made), the artist tried to convey the contrast of the everyday life of different categories of villagers and inform future generations. He did the same thing in his diary. These are brilliant strokes to the portrait of a Ukrainian village in the summer of 1933.

How many students appeared to be prepared for such a work? Could all be able to fulfill the tasks of collection of grain for the State grain stockpile, despite suffering and desperation of the peasants? How did they live later with this burden?

It should be noted, firstly, that the reports of institutes emphasize the shock work of students and teachers in the villages. Particular emphasis was given to voluntariness of this work, for example, in the summer of 1933, when colleges of universities declared themselves mobilized for the harvesting campaign for a month. They were proud of the fact that "there was a hard work without a break in the conditions onto absence of food and water during the day" 62.

Along with the praises to the authorities, in the reports "the enemies" of the socialist construction have traditionally been exposed. Not all of them, of course,

60 Там само. - Арк.9.

61 Там само. - Арк.11.

${ }^{62}$ ЦДАВО України. - Ф.166. - Оп.11. - Спр.148. - Арк.105. 
but a few, to show the vigilance of party committees. The documents deliver talks about the state of the peasants in the students' environment, teachers' statements, jokes. They are similar to those that could be heard everywhere. For example, Nizhyn Institute of Social Education reported that among students the question was discussed: "When will Stalin die?". Common statements were: "The party's decisions are nonsense, nothing good will happen as the result", "Stalin and the leaders do nothing, there are no achievements", "People are dying so that there are not enough planks for coffins to bury", "What can be said about the construction of socialism, when people die", "How can you study if you are hungry?". And the student Strykun shared an anecdote: "When a horse, a donkey and an ox came to Petrovskyi to get help, only the donkey got it, because only its relatives are sitting in the government - only donkeys" ${ }^{63}$.

Similar conversations were recorded at higher educational establishments in other regions: "The village now needs material, financial help, sending people to the villages will not help", "Collective farms mess up because the peasants were forced to go there" 64 .

The category of silent protests included the refusals to write reports on work in the villages. For example, a student of Zhytomyr Institute of Social Education Dashkul, on demand, to submit such a report, said: "What can I write about? The way in which peasants die from hunger in the countryside?"65.

Several key strategies for mobilizing young people can be determined:

1. As D.Hoichenko, who in his student's years had to be a collectivizer and a worker on grain collection, wrote that only the greatest rascals or completely blinded fanatics could remain indifferent to such crimes. Apparently, a significant part of the youth belonged to the category of fanatics. Therefore, the usual feelings of pity or shame, were suppressed, according to L.Kopelev, by precisely "rationalist fanaticism". The sources of this fanaticism were political, stemming from all sorts of meetings, in which the party resolutions and the speeches of the leaders of the state were worked out. The students were called to "show that they fulfilled the tasks assigned to them with honor" in a variety of campaigns, and they proved their loyalty ${ }^{66}$. They were ready for "an irreconcilable struggle for implementing the party's general line against the right mavericks and against the left wingers". They were convinced that "a delay with the haymaking and thrashing is a kurkul's maneuver aimed at breaking up the haymaking and thrashing" "67.

Yet, according to L.Kopelev, "the more persuasive were those people who embodied in my eyes, our truth and our justice, those who confirmed by their lives that it is necessary, setting their teeth and locking the heart, to do all that the Party and Soviet power commanded to do"68.

63 Там само. - Арк.60.

${ }_{64}^{64}$ ЦДАГО України. - Ф.1. - Оп.20. - Спр.5558. - Арк.104.

65 ЦДАВО України. - Ф.166. - Оп.11. - Спр.148. - Арк.105.

${ }_{66}$ Студенти разом з колгоспниками збирають врожай // Шлях соціалістичної реконструкції (Харків). - 1933. - 30 липня.

${ }_{67} K$-дент. Геть з комсомолу та інституту Шиліних і подібних // Там само.

68 Копелев Л. И сотворил себе кумира. - С.259. 
2. Refusals from trips to villages and the so-called "desertion" from the sowing front demonstrated both teachers and students. For example, when the brigade was organized to eliminate the "breakthrough" in the village of Prykolotne of the Velykoburlutskyi district in Kharkiv Geodetic Institute "there were the Komsomol members, who spoke a lot about the village, were considered activists, but refused to go"69. As a rule, students motivated their refusal by the fact that they did not want to lag behind in their academic studies.

The teachers who were not members of the party refused to go for economic and political campaigns, as they believed these events to be an affair for the Communists. For example, a staff member of Uman Institute for Social Education, Burstein, did not go to the village twice, noticing: "Collection of grain is an affair for the Communists, let them go to the village"70. However, Communists also refused to be mobilized and escaped from the villages. For example, a student of Odesa Milling Institute Abram Finkelshtein, who was sent to Holovanivskyi district for organization of cultural and propaganda work, having received another assignment, refused to work. Referring to the illness and the need to complete studies, he simply escaped from the village ${ }^{71}$.

Those who could got a variety of references ${ }^{72}$. The student Shylina asked to give her a telegram from her hometown having the following content: "Ira, immediately come home, Troshka is passing away"73. It was noted that this case was not an isolated one. The head of a student brigade, created at Dnipropetrovsk Railway-Building Institute of Transport Engineers for harvesting Amelin, "brought students to the station, but then returned home with some leaders and, as the result, broke up the labor campaign, because they were some other people, who also deserted from the labor camp, looking at the leaders"74.

Desertion was particularly wide spread during the Holodomor, even among the students who were party members. The party organizations began to ring the alarm, noting that if all the deserters were expelled from the party, no party members would be left in the party organizations. Markin, the secretary of the district party organization of the village of Kryve Ozero, Odesa region, asked to give him instructions on the punishment of deserters, "since now the tendency to escape from the area is gaining in mass character, no educational effect can help and we cannot exclude such a great number of people from the party"75.

3. Staying in the villages, the students often did not want to put up with the plans of excessive collection of grain for the state grain stockpile. Therefore, for example, they tried to prove to the supreme state leadership the unreality of such plans. So, the student of the IV year of Kharkiv Engineering and

69 Дезертири зазнали поразки // Студент революції. - 1933. - №7/8. - С.3.

70 ЦДАВО України. - Ф.166. - Оп.11. - Спр.148. - Арк.21.

71 Держархів Одеської обл. - Ф.11. - Оп.1. - Спр.108. - Арк.76.

2 Шnорт A. Беззаконня: Нотатки репресованого. - С.8.

3 -дент. Геть з комсомолу та інституту Шиліних і подібних.

${ }^{74}$ M.К. Із матеріалів ревізійної комісії // За темпи та якість: Орган колективів КП(б)У, ЛКСМУ, профкому, МК Робос, дирекції та робітфаку залізнично-будівельного інституту інженерів транспорту (Дніпропетровськ). $-1932 .-5$ серпня.

75 Держархів Одеської обл. - Ф.11. - Оп.1. - Спр.108. - Арк.79. 
Economics Institute Soroka, who was mobilized to the village of Tarasivka of the Troitskyi district (now Luhansk region), where he stayed from 9 September to 28 December 1932, wrote a report to the Central Committee of the party. In this report, he tried to prove the unrealistic expectations of the grain collection plan, which resulted in the economic base of the village being undermined. The Central Committee, in turn, concluded that the student had a "kurkul's mood" and regarded the "class struggle with kurkuls" as undermining the economic base of Tarasivka ${ }^{76}$. A student of Chervonohrad Agrotechnical Institute, a member of the Lenin Communist Union of Youth of Ukraine Bureau P.Dniprovskyi, who was sent for the collection of grain, was impressed by the situation of the peasants, and wrote a letter to the District Committee of the LCUYU, where he expressed his opinion concerning "the badness of the general line of the party in the execution of the grain collection policy". For this letter he was expelled from the Komsomol and the high educational establishment with a deprivation of the right to enter higher schools for three years ${ }^{77}$.

4. They made themselves insane. For example, as it was outlined in the memorandum, the nine party members out of the "300" students mobilized in the Kryvoozerskyi district, "imitated insanity". So, student Waltz's initially came into work, to later petition that he was ill and should be absolved from working in the region, pretending that he can do nothing, remembers nothing, can understand nothing, simulates to be stupid". And the student Prostota resorted to other tricks:

\begin{abstract}
"Once he came to the dining room and in the presence of a huge number of people, he took off his boots and began to trim the nails on his legs, or gets into a big mire and is wandering in it, or standing in the street turning to all sides, laughing at people unfamiliar to him. [...] They were wandering around the city for days and discredited the party organization by their actions"78.
\end{abstract}

It was also noted that such anti-party actions were made also by a number of party members.

5. Some students, unable to withstand the psychological load, expressed their protest against grain collection by committing suicide. In a memorandum addressed to the secretary of the Central Committee of the CP(b)U, S.Kosior, a series of students' suicides was reported, among them, for example, Oleksandr Hrebeniuk. On December 28, 1932, after the meeting, he said that it would be difficult for him to cope with the tasks set before him, that in general he did not know agriculture, and the conditions of work at MTS are unfamiliar for him. The next day he was found shot in an apartment house of the MTS ${ }^{79}$. The student Mushynskyi, who was an authorized person in the village of Sosovka, Zinovievskyi district cut his throat with a knife. Shortly before, he was saying:

76 Держархів Харківської обл. - Ф.1148. - Оп.7. - Спр.62. - Арк.1.

77 Терук В. Машкару зірвано // Студент револющії. - 1933. - №4. - С.32.

78 Держархів Одеської обл. - Ф.11. - Оп.1. - Спр.108. - Арк.79.

79 ЦДАГО України. - Ф.1. - Оп.20. - Спр.6395. - Арк.22. 
"We are finishing to harvest, and we still have to transport 5500 centers, of which 2000 are centers of wheat, and where I can get this wheat, I do not know" 80 .

As we can see, not all the students could stand hardening by hatred and cruelty. P.Hryhorenko and V.Bohdan reported about such activists who lost their illusions. "In these conditions, I cannot live any more. If they will not take me back, I'll kill myself", - said a student of Kharkiv Engineering and Construction Institute Ya.Zlochevskyi, when in 1933 he was once again sent to grain collection $^{81}$. The commissions investigating suicide cases explained these actions by the fact that mobilization into the village caused confusion, fear, frustration. Sometimes the conclusions were tougher. L.M.Savytskyi, for example, was accused of being "meshed in the kurkul nettings, dropped the general line of the party, lost courage in front of the class enemy", so he shot himself ${ }^{82}$. Not being able to withstand the totalitarian system, people voluntarily died and attempted at least to attract the attention of the general public to the true state of things in the society by their suicides. There is no need to speak about the impact of these cases on the system itself.

As a rule, such cases were considered by the directorate and public organizations of the institutes. They could deprive students of their diploma, a scholarship and refer the case to the public prosecution office. In Kherson Cotton Production Institute named after O.D.Tsiurupa during the grain collection period of 1931-32, eight students with a "kurkul ideology" were found and excluded from the institute ${ }^{83}$. The same number of students was excluded from Lubny Institute of Social Education for "malicious non-fulfillment of grain collection" and one more student - for a connection with the kurkuls. The thoughts that students came to study, and not to do a public work, were exposed and condemned ${ }^{84}$.

Sometimes the students were outraged by such a decision and appealed to the authorities with requests to bring them back to the institutes. For example, V.Chornyi, who refused to go for six months as a secretary of the collective farm "because he is not familiar with this activities and is still young (born in 1915, the term of service in KSM is 1 year)", complained in a letter to V.P.Zatonskyi: "It is enough for me to get a party punishment. Why have you expelled me from the technical school?"85.

Those who were not excluded were evicted from the hostel, deprived of ration cards, without which it was simply impossible to survive. In addition, in the periodicals, appeals to the students appeared, which called "to cover the names of the deserters of the sowing front with a black spot of the proletarian shame" 86 .

Thus, the analysis of the students' participation in collectivization, sowing, collection of grain and crop harvesting campaigns shows their significant role in carrying out these activities. The high school was transformed into an

80 Там само. - Арк.20.

81 Григоренко П.Г. Спогади. - К., 2007. - С.96.

82 ЦДАГО України. - Ф.1. - Оп.20. - Спр.6395. - Арк.47.

83 Держархів Одеської обл. - Ф.11. - Оп.1. - Спр.95. - Арк.69.

84 ЦДАВО України. - Ф.166. - Оп.11. - Спр.148. - Арк.134.

85 Там само. - Спр.331. - Арк.28.

86 Р-к K. На соціалістичні лани рушайте! // Студент революції. - 1933. - №4. - С.2-3. 
inexhaustible source of a constant supply for local Soviet structures, for replenishing the brigades of collectivists and liquidators of numerous gaps (in the terminology of that time - "breakthroughs") of Soviet construction. It is no coincidence that the students called themselves "a cork, which is used to stop all the holes". If we consider the problem from this point of view, the purpose of a significant increasing of the number of higher educational establishments in the Ukrainian SSR in the early 1930s becomes clear. For example, in 1929 there were only 38 institutes but in 1933 the republic had 190 institutions of higher education and, respectively, an increased number of the students in them. No one was going to keep such a great amount of young people in institutes for a long time, providing them with a thorough education. It is not surprising that all newly created institutions were not provided with premises, equipment, the teaching staff with appropriate qualifications, and the students were not provided with scholarships, hostels and meals. A detailed analysis of these issues was carried out in my monograph ${ }^{87}$. Educational processes with a systematic "political training" and a party pressing influence on the students' consciousness and behavior were designed to include them in the political struggle and mobilization campaigns. Therefore, it is not surprising that such missionaries had to "be vigilant and irreconcilable to enemy propaganda"; they undoubtedly organized collective farms, sought and took away the hidden grains, expropriated adults and children, generally, they supplemented the party constraint with the elements of "natural self-development" in those segments of the everyday life transformation, where the traditional society maintained the most conservative resistance.

\section{REFERENCES}

1. Andriewsky, O. (2015). Towards a Decentred History: The Study of the Holodomor and Ukrainian Historiography. In A.Makuch and F.E.Sysyn. (Ed.). Contextualizing the Holodomor. The Impact of the Thirty Years of Ukrainian Famine Studies. (18-52). Edmonton; Toronto: Canadian Institute of Ukrainian Studies Press. [in English].

2. Fitzpatrick, Sh. (1979). Education and Social Mobility in the Soviet Union, 19211934. Cambridge: Cambridge University Press. [in English].

3. Fitspatrik, Sh. (2001). Stalinskie krestyane. Soczialnaya istoriya sovetskogo obshchestva: derevnya. (L.Yu.Pantina, Transl.). Moskva: Rossijskaya politicheskaya entsiklopediya. [in Russian].

4. Havriuk, P.A. (1971). Robitfak industrialnoho hihanta. Spohady. Ukrainskyi istorychnyi zhurnal, 1, 104-106. [in Ukrainian].

5. Harkavenko. (1930). Bazhaiemo uspikhu. 4-i kurs torhfaku vyrushyv pershyi. Student Zhovtnia. Kharkiv, February 22. [in Ukrainian].

6. Hladshtein. (1931). Studentstvo KhIRBP v borotbi za zbir urozhaiu. Student Zhovtnia. Kharkiv. July 5. [in Ukrainian].

7. Gojchenko, D. (2012). Krasnyj apokalipsis: skvoz raskulachivanie i golodomor: Memuary svidetelya. Kiev: A-Ba-Ba-Ha-La-Ma-Ha. [in Russian].

87 Рябченко О. Студенти радянської України: практики повсякденності та конфлікти ідентифікації. - Х., 2012. 
8. Honchar, O. (2008). Shchodennyky (1968-1983). (Vol.2). Kyiv: Veselka. [in Ukrainian]. 9. Hryhorenko, P.H. (2007). Spohady. Kyiv: Ukraina. [in Ukrainian].

10. Kanevski A. and N. (1931). Studentstvo u borotbi za druhu bilshovytsku vesnu. Student Zhovtnia. Kharkiv, April 13. [in Ukrainian].

11. Kobyletskyi, Yu. (1985). Dal makhne krylom. Kyiv. [in Ukrainian].

12. Konkvest, R. (1993). Zhnyva skorboty: Radianska kolektyvizatsiia ta holodomor. (Transl.). Kyiv: Lybid. [in Ukrainian].

13. Kopelev, L. (2010). I sotvoril sebe kumira. Kharkov: Prava liudyny. [in Russian].

14. Kulchytskyi, S. (2013). Holodomor 1932-1933 rokiv u svitli ostannikh doslidzhen. Svitohliad, 5 (43), 70-79. [in Ukrainian].

15. Lynne, V. (1987). The Best Sons of the Fatherland: Workers in the Vanguard of Soviet Collectivization. New York; Oxford: Oxford University Press. [in English].

16. Matviienko, A.M. (2016). Kharkov. KhINO-KhPIPO. In: V.Yu.Ivashchenko (Ed.). Kharkivskyi universytet (1917-1941 rr.) u spohadakh yoho vykladachiv ta vykhovantsiv. (pp.111-121). Kharkiv: Vyd. KhNU im. V.N.Karazina. [in Russian].

17. Myroshnyk, P. (1931). V borotbi za druhu bilshovytsku. Za mekhanizatsiiu ta elektryfikatsiiu silskoho hospodarstva. Kharkiv. [in Ukrainian].

18. Plakhtin, I. (1982). Lita-dorohy: Spohady. Simferopol: Tavriia. [in Ukrainian].

19. Radkevych. (1930). Hurynivka maie buty zrazkovym kolhospom. Shefbryhady na dopomohu selu. Student Zhovtnia. Kharkiv. February 22. [in Ukrainian].

20. Ryabchenko, O. (2012). Studenty radianskoi Ukrainy 1920-1930-kh rokiv: praktyky povsiakdennosti ta konflikty identyfikatsii. Kharkiv: KhNAMH. [in Ukrainian].

21. Teruk, V. (1933). Mashkaru zirvano. Student revoliutsii, 4, 32. [in Ukrainian].

22. Voloshyna, S. (1933). Vyznaty pomylku - vypravyty khybu. Student revoliutsii, 7-8, 5-6. [in Ukrainian].

23. Shport, A. (1991). Bezzakonnia: Notatky represovanoho. Kyiv. [in Ukrainian].

\title{
ОльГА РЯБченко
}

докторка історичних наук, професорка, завідувачка кафедри всесвітньої історії,

Харківський національний педагогічний університет ім. Г.Сковороди

(Харків, Україна), lerche555@ukr.net

ORCID: https://orcid.org/0000-0002-1249-2482?lang=en

\section{МОБІЛІЗАЦІЯ МОЛОДІ ДЛЯ УЧАСТІ В КОМУНІСТИЧНИХ ПЕРЕТВОРЕННЯХ НА СЕЛІ В РОКИ КОЛЕКТИВІЗАЦІЇ ТА ГОЛОДОМОРУ}

\begin{abstract}
Анотація. Мета дослідження - аналіз участі студентів і викладачів вищих навчальних закладів радянської України в колуністичних перетвореннях на селі в роки колективізацї та Голодолору й окреслення їхньої ролі в організацї штучного голоду. Методологія дослідження базуеться на приниипах історизму, науковості, міждисииплінарності, антропоцентризму. Для розкриття проблели використано метод соціокультурного аналізу, а також традииійні конкретно-наукові методи: історико-генетичний, проблелно-хронологічний, колпаративний, типологічний. Наукова новизна. У статті на основі широкого кола джерел, серед яких особливе місце належить его-докулентал (щоденникал, листам до органів влади, неопублікованим спогадал), аналізуеться участь студентів $і$ викладачів вишів республіки в колуністичних перетвореннях на селі в роки колективізацї та Голодомору.
\end{abstract}


Виділено стратегї поведінки студентів щодо виконання постанов про участь у хлібозаготівельних і збиральних калпаніях, фборли їх протестів. З'ясовано, що кріл традииійних розлов стосовно становища селян та антипартійних анекдотів, які розповсюджувалися в інститутах, значна кількість студентів психологічно виявилися неготовили проводити ию роботу. Вони відловлялися їхати у села, тікали звідти, удавали з себе божевільних, писали листи до органів влади з критикою політики партї̈ на селі. Крайніл пролвол протестів були салогубства, що розцінювались як "розгубленість" перед "класовил ворогом", боязнь, невіра у свої сили. Виділено види покарань, застосовуваних до студентів, котрі відмовлялися від роботи на селі. Розкрито ставлення студентів і викладачів до селян та взаємини з нили. Уводиться в обіг щоденник директора Харківського художнього інституту, відомого художника А.Колашка, в яколу яскраво висвітлюеться життя селян $і$ родини голови Великобагачанського районного фбінансового відділу Ф.Нечитайла, шо мешкала у селі Затін (нині Полтавська обл.). Висновки. Аналіз участі студентів у колективізації, посівних, хлібозаготівельних і збиральних калпаніях свідчить про ваголу їх роль у проведенні цих заходів. Вишу школу перетворили на невичерпне джерело для постійного підживлення місиевих радянських структур, для поповнення бригад колективізаторів і ліквідаторів численних прогалин у "радянському будівниитві».

Ключові слова: студенти, викладачі, Голодомор, мобілізація, селяни, хлібозаготівлі. 